\title{
Giant Brain Hydatid Cyst in an Adult: A New Case Report
}

\author{
Bir Yetişkinde Dev Beyin Hidatik Kisti: Yeni Bir Olgu Sunumu \\ (1) Kazem Ghaemi ${ }^{1}$, (1) Mohamad Ali Masoudifar ${ }^{1}$, (1) Marouf Mehdi ${ }^{1}$, (1) Rahmat Solgi², \\ (D) Amir Tavakoli Kareshk ${ }^{2}$
}

${ }^{1}$ Birjand University Faculty of Medicine, Department of Neurosurgery, Birjand, İran ${ }^{2}$ Birjand University Faculty of Medicine, Infectious Disease Research Center, Birjand, İran

Cite this article as: Ghaemi K, Masoudifar MA, Mehdi M, Solgi R, Kareshk AT. Giant Brain Hydatid Cyst in an Adult: A

New Case Report. Turkiye Parazitol Derg 2021;45(1):76-79

\begin{abstract}
Cystic echinococcosis is an important zoonotic disease that occurs in humans and mammals in general, which causes considerable economic loss and poses health concerns in different parts of the world. The patient involved in this case report was a 28-year old man living in Birjand city who had been suffering from intermittent headache, nausea and vomiting for the past two weeks. The other symptoms presented by the patient were dizziness, blurred vision, seizures and imbalance. The patient only complained of headache in the last two weeks and had no symptoms of visual or speech impairment. He had a history of consuming raw vegetables, but did not have canine contact. In brain computed tomography and magnetic resonance imaging, a large cyst was evident in his brain. The patient was admitted to Razi Hospital in Birjand and followed-up by surgical treatment of the hydatid cyst, with no complications observed.
\end{abstract}

Keywords: Hydatid cyst, brain, Birjand

\section{Öz}

Kistik ekinokokkoz, insanlar ve memelilerde; dünyanın farklı bölgelerinde dikkate değer ekonomik kayıplara ve halk sağlığ sorunlarına neden olan önemli bir zoonotik hastalıktır. Birjand şehrinde yaşayan 28 yaşındaki erkek hasta son iki hafta içinde zaman zaman başağrısı, mide bulantısı ve kusma geçiren bir giyim satıcısıydı. Diğer belirtiler baş dönmesi, bulanık görme, nöbetler ve dengesizlikti. Hasta sadece son iki hafta içinde başağrısından yakınmaktaydı ve görme bozukluğu veya konuşma semptomları yoktu. Hasta çiğ sebze tüketme öyküsünden bahsetti fakat köpekle temas öyküsü bulunmuyordu. Bilgisayarlı beyin tomografisi ve manyetik rezonans görüntülemede beyinde büyük bir kist görüldü. Hasta Birjand'da Razi Hastanesi'ne yatırıldı ve herhangi bir komplikasyon olmadan kist hidatik cerrahi tedavisi ile takip edildi.

Anahtar Kelimeler: Hidatik kist, beyin, Birjand

\section{INTRODUCTION}

Hydatid disease, a significant health problem in many developing countries, have a complicated life cycle composed of canine as a definitive host and ruminant and accidentally human as an intermediate host. The more common cause of this disease is Echinococcus granulosus (E. granulosus) (1,2). In different countries, especially in countries where animal husbandry is prevalent, such as South Africa, Chile, Paraguay, Argentina, Australia, Tanzania, Brazil, Siberia, Turkmenistan, Mongolia, North China, South Japan,
Vietnam, Palestine, Syria, Iraq, Iran, Saudi Arabia, Israel and so on, as such native (endemic) exists. This disease is one of the occupational diseases that has been seen in shepherds and butchers $(3,4)$. Hydatid diseaseis commonly found in all parts of Iran and is the most important worm for causing disease, infectious lesions, complications and mortality in the country $(5,6)$. Here we present an adult patient with a giant brain hydatid disease and non-specific symptoms, who was treated successfully by surgery.

Received/Geliş Tarihi: 21.02.2020 Accepted/Kabul Tarihi: 27.08.2020

Address for Correspondence/Yazışma Adresi: Amir Tavakoli Kareshk, Birjand University Faculty of Medicine, Infectious Disease Research Center, Birjand, İran

E-mail/E-posta: atk9388@gmail.com ORCID ID: orcid.org/0000-0001-8216-0734 


\section{CASE REPORT}

The patient was a 28-year-old man living in Birjand city and a clothing seller who had been suffering from headaches, nausea and vomiting from time to time for the past two weeks. The patient has no history of diabetes, hypertension, aspirin or warfarin use. The patient only complained of headaches in the last two weeks and had no symptoms of vision impairment, or speech. In cervical vertebrae, the head was symmetrical and the neck was symmetrical in the midline. There was no movement defect in the examination of the limbs, and the strength of the limbs was 5.5. In brain (cephalic) computed tomography (CT), a large cyst was evident in brain. A magnetic resonance imaging (MRI) of the brain without an injection showed a large, unrestricted cyst in the diffusion weighted imaging images on the front of the brain in
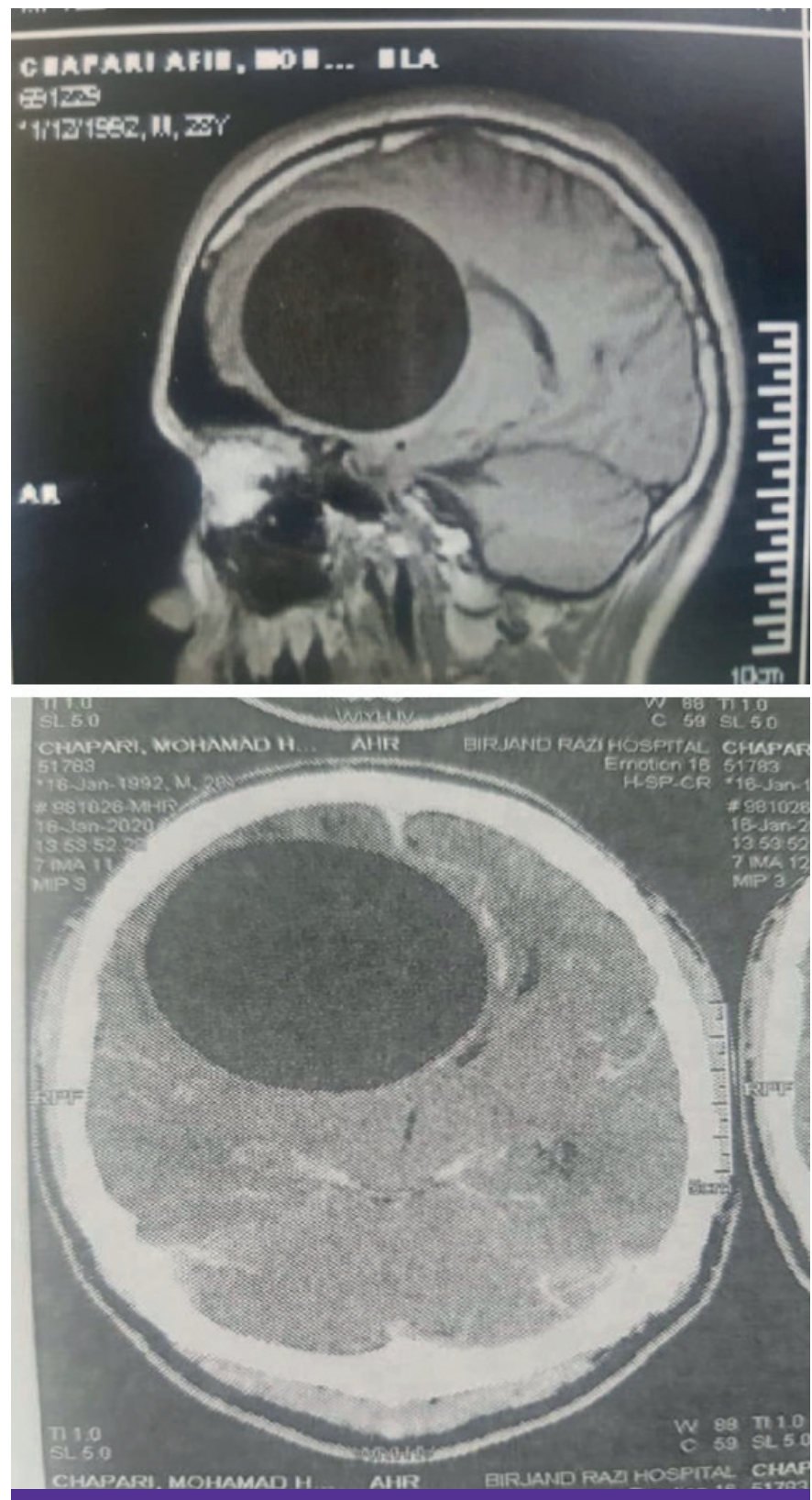

Figure 1. Brain MRI shows a large brain hydatic cyst in the left frontoparietal

MRI: Magnetic resonance imaging the right hemisphere, which was accompanied by pressure on the flex, ventral, and temporal lobes (Figure 1). Moderate peripheral edema was also observed. Initially, a differential diagnosis of arachnoid cyst was considered for the patient. No evidence based on fluid accumulation was observed on MRI. In Post fossa, no lesions were seen in the cerebellum and nerve nuclei 7 and 8 . In the skull, the anatomical signals and landmarks were reported to be normal. The bone flap was placed around its location, and due to the size of the craniotomy, the rest of the flap I removed was repaired with a mesh. It was sewn under the skin and the patient was transferred to the intensive care unit and after a few days he was discharged in good general condition. In the initial evaluation of the patient at the beginning of hospitalization; the patient was conscious and oriented. He had no history of specific illness, family illness, blood pressure, and sleep disorder. The patient had no cardiovascular, respiratory, gastrointestinal, genitourinary, skin, musculoskeletal, or psychological problems. Laboratory results showed that patient did not have leukocytosis but had eosinophilia (12\%). Further laboratory and imaging findings were normal (white blood cell: 9.46, red blood cell: 5.15, hemoglobin: 14.7, hydrochlorothiazide: 44.7 , mean cell volume: 86.8 , mean corpuscular hemoglobin: 28.5, mean corpuscular hemoglobin concentration: 32.9 , platelet: 264,000, partial thromboplastin time: 31.1, prothrombin time: 14.1, international normalized ratio: 1.2, fasting blood sugar: 79 , urea: 31 , chromium: 0.98). In chest X-ray, it had multiple cystic areas, and in the liver and spleen, it had multiple cysts (Figure 2).

The patient was admitted to Razi Hospital in Birjand with a diagnosis of brain cyst and an infectious disease consultation was

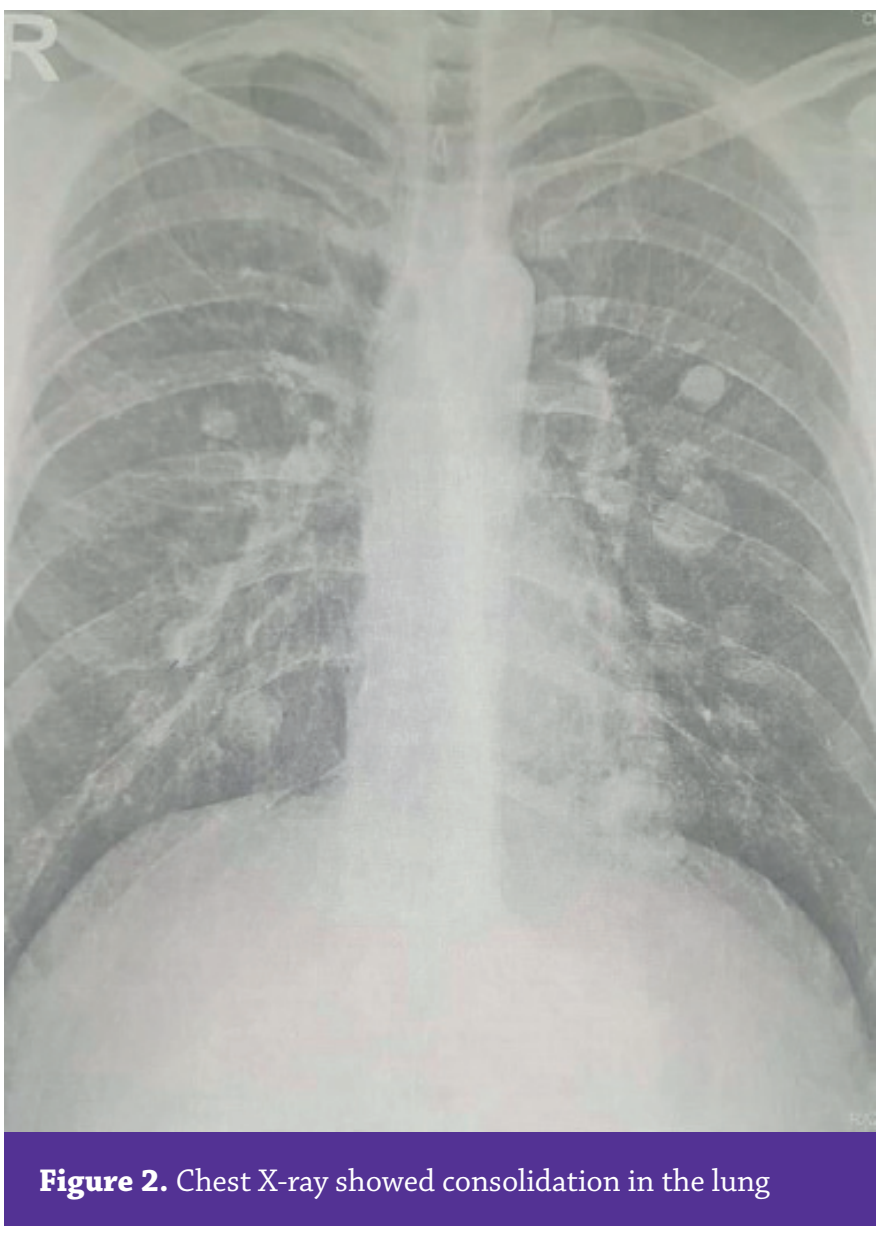


requested and then consent was obtained from the patients for publication of this report and accompanying images. Hydatiddisease was considered highly probable in an infectious disease consultation and medical therapy such as albendazole usea before surgey. In total, the patient underwent surgery twice at Razi Hospital in birjand. Craniotomy surgery was performed for 3.5 hours, and after craniotomy and duratomy and removal of the bone flap, the flap was placed under the skin of the abdomen and the continuation of the surgery was assigned the next time. One week after the first operation cyst with dimensions of $90 \times 40 \mathrm{~mm}$ were successfully removed from the patient's brain with a second operation (Figure 3, 4).
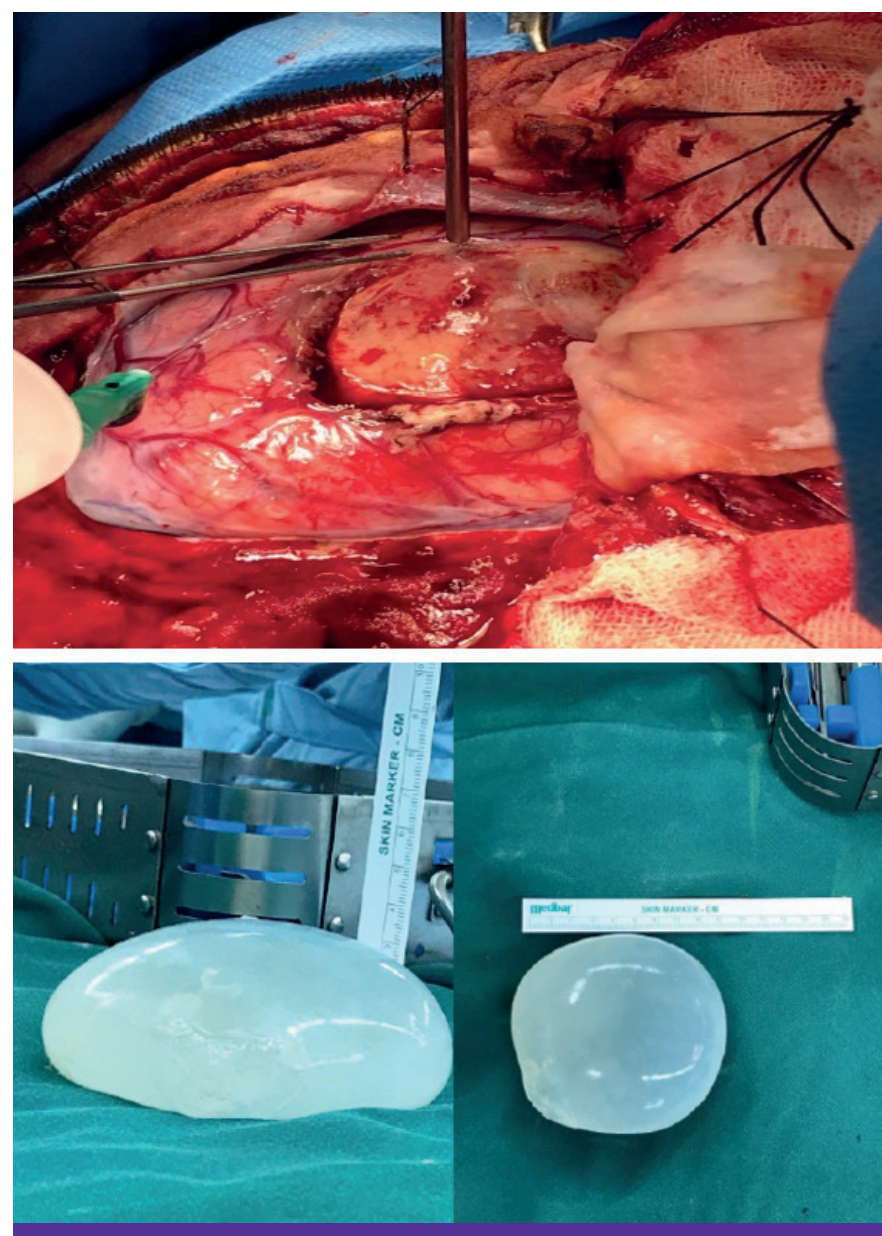

Figure 3. Surgical excision of the brain hydatid cyst

\section{DISCUSSION}

Cystic echinococcosis is a zoonotic parasite disease caused by E. granulosus. The definitive host of this helminthic parasite is canine, while the wide range of domestic and wild animals serve as intermediate hosts. Human act as accidentally intermediate host for this parasite and infected by ingestion of E. granulosus eggs through faeces of infected canine (7). Cystic echinococcosis mainly involved extracranial organ such as liver and lungs but in rare cases it can cause intracranial infection (6). The $C E$ of brain is only account for up to $2 \%$ of all intracranial space-occupying lesions (8). This form of $C E$ is occurred commonly when

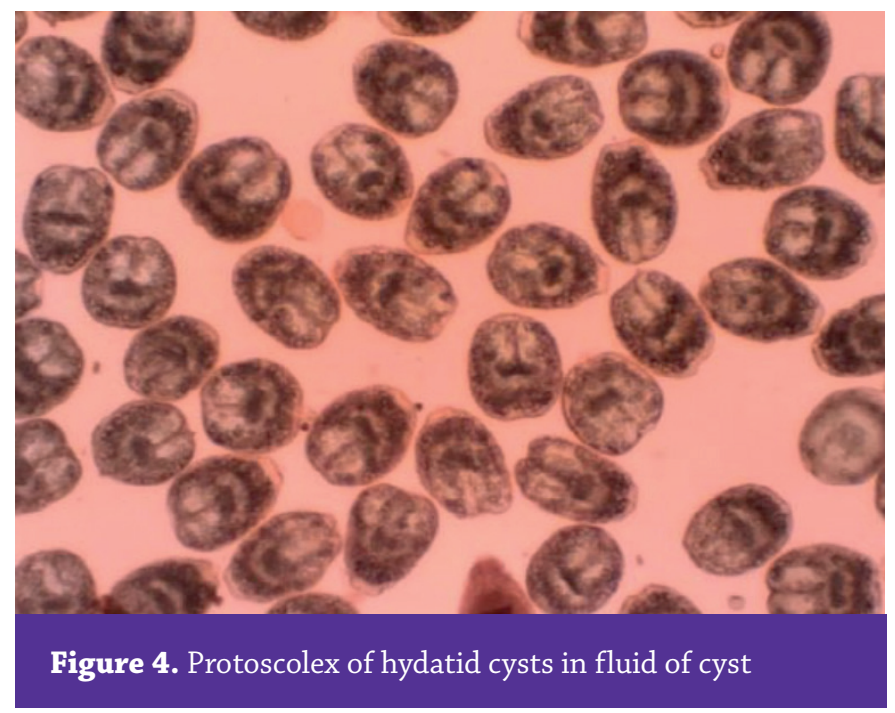

protoscoleces escape through the hepatic, pulmonary, and cardiac filters and reaches the brain and often presents as a singular (9). In rare it was occurred by rupture of extracranial cyst surgically of by trauma and it is often seen multiple (10). Also, in studies, the CE patient reported diplopia, ataxia, hemiparesis and even coma. In the current case report, patient just presents a non-specific sign such as degree of headache and vomiting. Hydatid disease is usually diagnosed by clinical findings, medical history, serological, and imaging methods. In case of cerebral hydatid disease, many results tend to be false negative by serological test, so the imaging evaluation such a CT and MRI lead to better result $(11,12)$. In the present case, both CT and MRI were used for diagnosis of brain CE. In CT, the cysts appear smooth, thin-walled lesions and round just like the cerebrospinal fluid. MRI is preferred in showing the cyst's wall compared to $\mathrm{CT}(7,13)$. In conclusion, rapid diagnosis and complete surgical removal of the brain $\mathrm{CE}$ are the main keys that led to a favourable outcome.

\section{ACKNOWLEDGEMENTS}

The authors would like to express deepest thanks to staff of Razi Hospital, Birjand University of Medical Sciences, Birjand, Iran.

\section{* Ethics}

Informed Consent: Consent was obtained from the patients for publication of this report and accompanying images.

Peer-review: Internally peer-reviewed.

\section{* Authorship Contributions}

Surgical and Medical Practices: K.G., M.A.M., M.M., Concept: K.G., M.A.M., M.M., A.T.K., Design: K.G., M.A.M., M.M., A.T.K., Data Collection or Processing: K.G., M.A.M., M.M., A.T.K., Analysis or Interpretation: A.T.K., Literature Search: R.S., A.T.K., Writing: R.S., A.T.K.

Conflict of Interest: No conflict of interest was declared by the authors.

Financial Disclosure: The authors declared that this study received no financial support.

\section{REFERENCES}

1. McManus DP, Zhang W, Li J, Bartley PB. Echinococcosis. Lancet 2003; 362: 1295-304 
2. Moro P, Schantz PM. Echinococcosis: a review. Int J Infect Dis 2009; 13 125-33.

3. Dziri C. Hydatid disease--continuing serious public health problem: introduction. World J Surg 2001; 25: 1-3.

4. Romig T. Epidemiology of echinococcosis. Langenbecks Arch Surg 2003; 388: 209-17.

5. Sadjjadi SM. Present situation of echinococcosis in the Middle East and Arabic North Africa. Parasitol Int 2006; 55: 197-202.

6. Heydari S, Taherpour S, Abbasimoghaddam A, Tavakoli Kareshk A. A Pulmonary Hydatid Cyst with Left Lung Involvement: A Case Report. Mod Care J 2019; 16: 95196.

7. Ciurea AV, Fountas KN, Coman TC, Machinis TG, Kapsalaki EZ, Fezoulidis $\mathrm{NI}$, et al. Long-term surgical outcome in patients with intracranial hydatid cyst. Acta Neurochir (Wien) 2006; 148: 421-6
8. Kızılca O, Altaş M, Senol U, Oztek MA. Hydatid disease located in the cerebellomedullary cistern. Case Rep Med 2014; 2014: 271365.

9. Darwazah AK, Zaghari M, Eida M, Batrawy M. Left ventricular endocardial ecchinococcosis associated with multiple intracranial hydatid cysts. J Cardiothorac Surg 2013; 8: 104.

10. Angın T, Çelebisoy M, Karatepe A, Fazıl Gelal M, Kübra Şirin H. Cerebral Hydatid Cyst: A Case Report 2014; 20: 87-90.

11. Reddy DR. Managing cerebral and cranial hydatid disease. Neurol India 2009; 57: 116-8.

12. Khaldi M, Mohamed S, Kallel J, Khouja N. Brain hydatidosis: report on 117 cases. Childs Nerv Syst 2000; 16: 765-9.

13. Ozkan U, Kemaloglu MS, Selçuki M. Gigantic intracranial mass of hydatid cyst. Childs Nerv Syst 2001; 17: 623-5. 